\title{
Struktury religijne na przykładzie „Atlasu wyznań i religii w Rzeczypospolitej w drugiej połowie XVIII w."
}

\author{
Bogumił Szady
}

\section{Wprowadzenie}

Kartografię historyczną sporadycznie uznaje się w literaturze przedmiotu za odrębny dział kartografii tematycznej. Mapy historyczne zaliczane są do różnych kategorii rzeczowych, zarówno fizycznogeograficznych, jak i społeczno-gospodarczych. W ostatnim podręczniku na temat kartografii tematycznej pod redakcją Wiesławy Żyszkowskiej, Waldemara Spallka i Doroty Borowicz odrębny fragment dotyczący kartografii historycznej został poświęcony jedynie mapom podziałów historyczno-geograficznych (podrozdział 6.3.4.4) jako podkategorii map społecznej organizacji przestrzeni. Ze względu na podejmowany $\mathrm{w}$ artykule problem struktur religijnych warto wspomnieć, że do tej samej kategorii zostały zaliczone mapy struktur administracyjno-kościelnych. Z kolei informacje na temat „Atlasu historycznego miast polskich” znalazły się w części poświęconej geografii osadnictwa ${ }^{1}$. Nieco inaczej sprawę ujęli Jacek Pasławski i Jerzy Siwek, wprowadzając dwa kryteria klasyfikacyjne: mapy tematyczne nauk geograficznych i niegeograficznych oraz mapy tematyczne przyrodnicze i społeczno-gospodarcze. W tej klasyfikacji mapy historyczne zostały ujęte jako mapy nauk niegeograficznych i mapy społeczno-gospodarcze ${ }^{2}$. Jedynie $\mathrm{w}$ raporcie na temat kartografii polskiej za lata 2011-2014 przygotowanym przez Beatę Konopską i Jerzego Ostrowskiego pod auspicjami Instytutu Geodezji i Kartografii w Warszawie oraz Polskiego Komitetu Narodowego

1 W. Żyszkowska, W.A. Spallek, D. Borowicz, Kartografia tematyczna, Warszawa 2012, s. 257, 269-270.

2 J. Pasławski, J. Siwek, Mapy tematyczne, w: Wrowadzenie do kartografii i topografii, red. J. Pasławski, Wrocław 2006, s. 308. ds. Międzynarodowej Asocjacji Kartograficznej projekty z zakresu kartografii historycznej znalazły odrębne miejsce wśród map i atlasów tematycznych obok map hydrologicznych, ekologicznych, geomorfologicznych, geologicznych i glebowych ${ }^{3}$.

W polskiej nauce mapy historyczne dotyczące religijnych i wyznaniowych struktur terytorialnych da się podzielić na dwa nurty. W pierwszym, który można określić jako główny, mapy oraz część kartograficzna stanowią najważniejszą i podstawową treść opracowań. Jest on związany z dwoma zespołami naukowymi pracującymi w sposób ciągły nad kartografią historyczną ziem polskich: Ośrodkiem Badań nad Geografią Historyczną Kościoła w Polsce (do 2010 r. Instytutem Geografii Historycznej Kościoła w Polsce) przy Katolickim Uniwersytecie Lubelskim Jana Pawła II oraz Zakładem (niegdyś Pracownią) Atlasu Historycznego przy Instytucie Historii Polskiej Akademii Nauk. W drugim nurcie mapy historyczne dotyczące struktur wyznaniowych mają charakter załącznikowy do opracowań monograficznych i artykułów.

Ujęty w tytule program Atlasu wyznań $i$ religii $w$ Rzeczypospolitej $w$ drugiej potowie XVIII $w$. związany jest z tradycją badań prowadzo-nych w Instytucie Geografii Historycznej Kościoła w Polsce, a w szczególności z osobą Stanisława Litaka jako inicjatora i pomysłodawcy tego opracowania. Ważną inspiracją były dla niego także, o czym pisał w 2006 r., prace

3 Cartographic Activities in Poland 2011-2014. National Report, ed. B. Konopska, J. Ostrowski, Warszawa 2015 (http://icaci.org/files/ documents/national_reports/2011-2015/poland.pdf, dostęp: 5 września 2015). 
nad „Atlasem historycznym Polski”. Warto przypomnieć, że na przełomie lat 60. i 70 . ubiegłego stulecia oba zespoły specjalizujące się w kartografii historycznej ściśle ze sobą współpracowały, wzajemnie się inspirowały oraz dzieliły swoimi doświadczeniami. 25 listopada 1966 r. odbyła się ogólnopolska sesja naukowa poświęcona działalności naukowej Instytutu Geografii Historycznej Kościoła w Polsce, w której uczestniczyli historycy związani z „Atlasem historycznym Polski”: Karol Buczek, Stanisław Herbst, Henryk Rutkowski i Marian Biskup 5. Z kolei Anna Dunin-Wąsowicz, Kazimierz Pacuski, Władysław Pałucki oraz Henryk Rutkowski prezentowali swoje doświadczenia dotyczące rekonstrukcji struktur religijnych (na przykładzie Mazowsza) w czasie międzynarodowego kongresu poświęconego kartografii i historii społeczno-religijnej, który odbył się w Warszawie w $1971 \mathrm{r}^{6}$

Większość artykułów poświęconych kartografii historycznej dotyczącej wyznań i religii koncentrowało się na przedstawieniu treści merytorycznej map, omówieniu źródeł oraz wyników dociekań analitycznych, które te mapy prezentują. Mniej uwagi poświęcano kwestiom teoretycznym i warsztatowym. Dotyczą one przede wszystkim trudności w reprezentacji kartograficznej zjawisk historycznych dotyczących życia religijnego. Program geografii historycznej religii i wyznań w polskich badaniach historycznych czerpał inspiracje głównie z francuskiej szkoły historii społecznej „Annales”. Na czoło wysunąć można tutaj nazwiska Gabriela Le Bras'a oraz Jeana Gaudemeta, zaś w historiografii polskiej - Jerzego Kłoczowskiego, który przeniósł francuskie inspiracje na rodzimy grunt. Cały program był bardzo obszerny $\mathrm{i}$ - biorąc pod uwagę okres jego formuło-

4S. Litak, Atlas Kościoła łacińskiego w Rzeczypospolitej Obojga Narodów w XVIII wieku, Lublin 2006, s. 24.

5 Ogólnopolska sesja naukowa z dnia 25 listopada 1966 r. poświęcona działalności naukowej Instytutu Geografii Historycznej Kościoła w Polsce, „Roczniki Humanistyczne”, 16 (2), 1968, s. 123-174.

6 Miscellanea historiae ecclesiasticae V. Colloque de Varsovie, 27-29 octobre 1971 sur la cartographie et l'histoire socio-religieuse de l'Europe jusqu'à la fin du XVIle siècle, Louvain 1974, s. 71-88 (Bibliothèque de la Revue d'histoire ecclésiastique, 61). wania - bardzo nowoczesny. W swoim charakterze nawiązuje on do „zwrotu przestrzennego” w naukach humanistycznych. Gabriel Le Bras ujął całość w czterech punktach, odnoszących się głównie do chrześcijaństwa:

1. „l'occupation du sol": budownictwo religijne i struktury terytorialne (procesy chrystianizacyjne, diecezje, archidiakonaty, dekanaty, parafie, zakony i klasztory itd.);

2. „la puissance ecclésiastique”: instytucje kościelne i warunki ich funkcjonowania (sądownictwo, synody, urzędy i beneficja, uposażenie, obsada itd.);

3. „l'activité religieuse”: praktyki religijne (wezwania, sakramenty, pielgrzymki, praktyki religijne itd.);

4. „la vie de l'esprit": podłoże umysłowe i duchowe (szkoły i uniwersytety, biblioteki, reforma protestancka). Główną metodą analiz porównawczych oraz prezentacji wyników badań miała być kartografia ${ }^{7}$.

Nieco inaczej problematykę systematyzował Jean Gaudemet, który wyraźnie nawiązywał do myśli Gabriela Le Bras'a. Problematykę geografii instytucji kościelnych ujmował w trzech punktach: 1. "l'occupation du sol"; 2. „la vie religieuse”, w którym łączył instytucje kościelne z życiem i praktykami religijnymi; 3. "le rayonnement social”, który wskazuje na społeczną interakcję instytucji religijnych ${ }^{8}$. Rozbieżność między „la vie de l'esprit” (Gabriel Le Bras) i "le rayonnement social” (Jean Gaudemet) jest tylko pozorna - obaj nawiązują bowiem do społecznej roli Kościoła oraz środowiskowych uwarunkowań jego funkcjonowania?. Jedną z najważniejszych cech programu badań nad geografią historyczną Kościoła - warto

\footnotetext{
7 G. Le Bras, Un programme: la géographie religieuse, „Annales d'histoire sociale", 8 (1), 1945, s. 87-112; J. Kłoczowski, Rozwój i problematyka badań nad geografią historyczną Kościoła Katolickiego, , Roczniki Humanistyczne", 11 (2), 1962, s. 5-93.

8 G. Le Bras, Un programme, s. 89-106; J. Gaudemet, Géographie ecclésiastique et histoire des institutions, w: Miscellanea historiae, s. 260-274.

9 „Les actes de la pratique sont bien souvent suggérés par l'imitation, imposés par la pression du milieu". G. Le Bras, Un programme, s. 106. "Les manifestations de la pratique religieuse introduisent déjà la vie de l'Église dans le domaine plus large de la vie social". J. Gaudemet, Géographie ecclésiastique, s. 274.
} 
dodać, że nie w pełni zrealizowanego - była „tendencja do nietraktowania zjawisk w izolacji, do wniesienia wkładu w lepsze zrozumienie i wyjaśnienie całokształtu przemian i struktur społecznych"10. Podstawowym narzędziem do zrozumienia tych procesów oraz ich ukazania były mapy.

Kartograficzne przedstawienie struktur religijnych i wyznaniowych w 2. poł. XVIII w. nawiązuje do punktu pierwszego wymienionych wyżej programów naukowych. Jak powiedziano wcześniej, jest ono inspirowane także pracami nad „Atlasem historycznym Polski”, zaś wprost stanowi kontynuację studiów nad organizacją terytorialną Kościoła łacińskiego w XVIII w. prowadzonych przez Stanisława Litaka $^{11}$. Zasięg terytorialny opracowania wyznaczają Rzeczpospolita Obojga Narodów, Śląsk (w granicach łacińskiej diecezji wrocławskiej) oraz Prusy Książęce ${ }^{12}$, zaś zasięg chronologiczny - 2. poł. XVIII w., możliwie precyzyjnie ok. 1772 r. Nie trzeba w tym miejscu prezentować szczegółowych założeń samego projektu, które były już kilkakrotnie referowane ${ }^{13}$. Więcej uwagi należy natomiast poświęcić problematyce kartograficznej prezentacji struktur wyznaniowych objętych projektem. Opracowania częściowe, które zawierają wyniki prowadzonych badañ ${ }^{14}$, obrazują rozliczne trudności związane z przejściem od opracowania atlasowego poświęcone-

10 J. Kłoczowski, Rozwój i problematyka, s. 78.

11 S. Litak, Atlas Kościoła łacińskiego.

120 zasadności włączenia Śląska oraz Prus Książęcych zob. S. Litak, Mapa wyznaniowa Rzeczypospolitej około 1772 roku (Religie - Wyznania Kościofy - Metoda opracowania), w: Jezuicka ars historica. Prace ofiarowane Księdzu Profesorowi Ludwikowi Grzebieniowi SJ, red. M. Inglot, S. Obirek, Kraków 2001, s. 350.

13 Tenże, Projekt wyznaniowej mapy Rzeczypospolitej w drugiej połowie XVIII w., w: Mapa w pracy historyka, red. T. Bogacz, B. Konopska, Wrocław-Warszawa 1999, s. 175-184 (Z Dziejów Kartografii, 11); tenże, The Atlas of Religious and Ethnic Relations in the Polish-Lithuanian Commonwealth in the Second Half of the $18^{\text {th }}$ Century, w: Churches, States, Nations in the Enlightenment and in Nineteenth Century. Eglises, états, nations a l'époque des Lumières et au XIXe siècle, ed. M. Filipowicz, Lublin 2000, s. 54-59; B. Szady, Z badań nad mapa wyznań i religii Rzeczypospolitej przed pierwszym rozbiorem Polski, w: Rzeczpospolita wielokulturowa - dobrodziejstwo czy obciążenie, red. J. Kłoczowski, Warszawa 2009, s. 21-27.

14 S. Litak, Kościót taciński w Rzeczypospolitej około 1772 r. Struktury administracyine, Lublin 1996; W. Kołbuk, Kościoły wschodnie w Rzeczypospolitej okoto 1772 r., Lublin 1998; B. Szady, Geografia struktur religijnych i wyznaniowych w Koronie w II potowie XVIII wieku, Lublin 2010. go jednej grupie wyznaniowej do ujęcia kartograficznego, w którym na wspólnej płaszczyźnie prezentowane są struktury wielu obrządków, wyznań i religii.

Głównym celem niniejszego artykułu jest przedstawienie procedur i metod rozwiązywania problemów dotyczących: 1 . harmonizacji wybranych informacji geograficzno-historycznych na temat struktur terytorialnych religii i wyznań, 2. ich prezentacji kartograficznej na mapie głównej. Jest ona przygotowywana w skali 1:300 000 i będzie się składała z czterech zasadniczych grup zagadnień: miejscowości, świątyń, granic oraz podkładu fizjograficznego. Pierwszorzędne znaczenie i tematyczną treść mapy będą stanowić obiekty sakralne oraz jednostki administracyjne poszczególnych wyznań. Miejscowości, granice państwowe i wojewódzkie, hydrografia (rzeki i jeziora), lasy i bagna składają się na część podkładową mapy.

\section{Świątynie}

Od samego początku badań nad strukturą Kościoła łacińskiego oraz Kościołów wschodnich nastąpiło - nastręczające istotne trudności - utożsamienie znaczeń terminów „wspólnota wyznaniowa”, „parafia”, ,świątynia”, „kościól"15. Już w ramach badań nad dziejami wyznań chrześcijańskich założenie takie powoduje rozliczne trudności, zwłaszcza przy próbie ujęcia kartograficznego dla wyznań protestanckich. Nakłada się na to dodatkowo wieloznaczność terminu „zbór” (parafia, gmina, świątynia) ${ }^{16}$. Nie kwestionując zasadniczej roli świątyni dla funkcjonowania wspólnoty wyznaniowej, z różnych powodów - politycznych i społeczno-ekonomicznych - istniały tego typu społeczności bez obiektów sakralnych, podobnie jak nie zawsze jego obecność oznaczała

\footnotetext{
15 „Poszczególne wspólnoty religijne i wyznaniowe zostaną naniesione na mape zgodnie z ich strukturami terytorialnymi - naniesione zostaną na mapę wszystkie świątynie: parafialne, filialne, zakonne i inne oraz ich podstawowe podziały terytorialne". S. Litak, Projekt wyznaniowej mapy, s. 351. W legendzie Atlasu Kościoła łacińskiego Stanisława Litaka z 2006 r. w tej samej kategorii sygnatur znajdują się: „parafia”, „kościół pomocniczy” $i$, „inna miejscowość".

16 A. Klemp, Protestanci w dobrach prywatnych w Prusach Królewskich od drugiej połowy XVII do drugiej połowy XVIII wieku, Gdańsk-Wrocław 1994, s. 144-146.
} 
(i oznacza współcześnie) funkcjonowanie przy nim zorganizowanej grupy religijnej ${ }^{17}$. Charakter świątyń i rola miejsc modlitewnych we wspólnotach były bardzo zróżnicowane i kształtowały się odmiennie w każdej konfesji. Wystarczy nadmienić, że już samo używanie terminu „świątynia” w stosunku do synagog i domów modlitwy z punktu widzenia religii mojżeszowej budzi poważne zastrzeżenia. Dlatego harmonizacja tego zagadnienia dla potrzeb ujęcia kartograficznego prowadzić musi do daleko idących generalizacji i uproszczeń.

Mimo że opracowania materiałowe - jak zostało powiedziane wcześniej - posługiwały się zamiennie określeniami „wspólnota wyznaniowa”, „parafia”, „świątynia” etc., treść zgromadzonego materiału dla potrzeb prezentacji kartograficznej dotyczy kościołów i świątyń. Wnioskowanie o ich istnieniu, oparte na bardzo zróżnicowanej podstawie źródłowej, ma najczęściej charakter bezpośredni. W przypadku większych miejscowości dla jednoznacznej identyfikacji budynku sakralnego wykorzystywane są informacje o wezwaniu, materiale budowlanym czy charakterze patronatu. Warto dodać, że ten ostatni element, charakterystyczny dla Kościoła katolickiego, należy wiązać właściwie z beneficjami funkcjonującymi przy kościołach, a nie z samymi świątyniami. Tylko sporadycznie - jak w przypadku niektórych synagog - brakuje informacji o budynku sakralnym $\mathrm{i}$ konieczne jest wykorzystanie informacji pośrednich. W tych przypadkach wzmianki o gminach żydowskich, muzułmańskich, karaimskich czy chrześcijańskich traktowane są jako wystarczające przesłanki do stwierdzenia istnienia świątyni. Zachowana jest tutaj jednak daleko idąca ostrożność, a wszelkie sytuacje tego typu i wątpliwości znajdują odzwierciedlenie w opracowywanym zestawieniu indeksowym, które będzie załączone do mapy wraz z komentarzem i mapami problemowymi.

Nie wszystkie wzmianki o miejscach modlitewnych oraz odbywających się praktykach traktowane są jako wystarczająca podstawa do

17 W. Kriegseisen, Stosunki wyznaniowe w relacjach państwo-kościót między reformacją i oświeceniem, Warszawa 2010, s. 645-646. umieszczenia świątyni na mapie. Obowiązują tutaj dwa główne kryteria kwalifikacji: formalne oraz funkcjonalno-architektoniczne. Jeżeli chodzi o stronę formalną, to projekt obejmuje świątynie publiczne istniejące ok. 1772 r., a pomija domy modlitwy oraz oratoria prywatne. Skala badań uniemożliwia szczegółowe rozpatrywanie statusu prawnego każdego obiektu, zwłaszcza w przypadku wyznań innych niż katolickie - uprzywilejowane ustrojowo w dawnej Rzeczypospolitej ${ }^{18}$. Jak doskonale wiadomo, budownictwo protestanckie oraz remonty istniejących świątyń podlegały istotnym ograniczeniom, zwłaszcza w XVIII w. Pomijane są w związku z tym liczne przypadki, szczególnie w Wielkopolsce, kiedy nie było stale funkcjonującej świątyni oraz duchownego, zaś nabożeństwa odbywały się w domach prywatnych i szkołach. Jednoznaczne rozstrzygnięcia o publicznym lub prywatnym charakterze świątyni są niekiedy bardzo trudne z powodu wąskiej podstawy źródłowej oraz zmieniającej się w czasie sytuacji. Należy pamiętać, że położenie ewangelików i prawosławnych w Polsce zaczęło się mocno zmieniać po $1768 \mathrm{r}$.

Jak trudne są to kwestie, może uświadomić przykład opisu zborów w miejscowościach $\mathrm{Ne}$ kielka (Nekla Hauland), Siedleczek (Siedlec Hauland) oraz Zaniemyśl (Santomischel).Z całą pewnością na mapie zostanie uwzględniona świątynia pomocnicza (zbór filialny) w Nekielce. Mimo że parafia powstała dopiero w poł. XIX w., literatura przedmiotu traktuje o kaplicy wybudowanej w $1754^{19}$ lub 1749 r. $^{20}$ i należącej do parafii we Wrześni. Prawdopodobnie o niej, jako jednym z oratoriów prywatnych, wspomina wizytator łacińskiej parafii w Nekli w 1779 r. ${ }^{21}$ Nie ma aż tak mocnego potwierdzenia źródłowego dla kaplicy w Siedleczku. Na podstawie informacji z wizytacji w $1777 \mathrm{r}$. trudno stwierdzić, czy oratorium prywatne w tym przypadku oznaczało kaplicę, czy tylko

\footnotetext{
18 Tamże, s. 618-619.

19 A. Werner, Geschichte der evangelischen Parochien in der Provinz Posen, Lissa 1904, s. 227.

20 S. Mazurkiewicz, Nekla. Historia miasta. Monografia na jubileusz 600-lecia, Września-Nekla 2007, s. 49.

21 AAP, AV31, s. 115, 1777 r.: „habent sua oratoria privata”.
} 
izbę $\mathrm{w}$ domu ${ }^{22}$. Z kolei $\mathrm{w}$ Zaniemyślu informacja o oratorium publicznym pojawia się w 1777 r. ${ }^{23}$, zaś Albert Werner wyraźnie stwierdza, że parafia powstała w latach 1775-1777 (a więc po 1772 r. $)^{24}$. $\mathrm{Z}$ tego samego powodu pominięty zostanie np. zbór $\mathrm{w}$ Jutrosinie. Wizytacja z 1778 r. wspomina co prawda „fanum et ministrum" 25 , jednak parafia ewangelicka została reaktywowana dopiero w 1776 r., a wizytacja wspomina pierwszego pastora, którym został w tym roku Johann Michael Bern$\operatorname{hardt}^{26}$. Mapa nie ujmie także zboru w Krotoszynie. Decyzja o powołaniu parafii zapadła na synodzie z 1788 r., zaś budynek powstał w 1790 r. $^{27}$

Wiele potwierdzonych źródłowo przykładów wskazuje na utożsamianie oratorium prywatnego i szkoły ${ }^{28}$. O płynności granicy między oratorium prywatnym i publicznym może świadczyć fragment protokołu wizytacji parafii w Przysiersku z 1780 r.: „Acatholici habent sua oratoria privata seu scholas et fere publicum in Bukowiec" (oratorium prawie publiczne ${ }^{29}$. Andrzej Mietz w monografii na temat archidiakonatu kamieńskiego archidiecezji gnieźnieńskiej wyraźnie odróżnia świątynie, kaplice i kaplice szkolne. $Z$ jednej strony podkreśla znaczenie tych ostatnich, które stanowiły „najprostsze w swej strukturze organizacyjnej i najmniej kosztowne - luterańskie ośrodki kultu religijnego", z drugiej zaś pisze o doraźnym charakterze struktury zborowej, którą nie sposób porównywać $\mathrm{z}$ katolicką siecią parafialną ${ }^{30}$. Problemy interpretacyjne może szczególnie dobrze ilustrować przykład zboru w Mirkowicach (Merckowitz), gdzie pojawia się

22 Tamże, s. 95, 1777 r.: „baccalaureum et oratorium privatum”. AAP, AV33, s. 86, 1777 r.: ,baccalaureum et scholam sive privatum oratorium".

23 AAP, AV31, s. 282, 1777 r.: ,oratorium publicum".

24 A. Werner, Geschichte der evangelischen Parochien, s. 333.

25 AAP, AV33, k. 564v, 1778 r.

26 A. Werner, Geschichte der evangelischen Parochien, s. 132-133. H. Merczyng, Zbory i senatorowie protestanccy w dawnej Polsce, w: W. Krasiński, Zarys dziejów powstania i upadku reformacji w Polsce, Warszawa 1905, s. 151.

27 ADWł, GAV86, s. 77, 1790 r.; A. Werner, Geschichte der evangelischen Parochien, s. 169.

28 Par. Świekatowo (,privata oratoria seu scholas". ADWł, AV43, k. 148v), par. Polskie tąki (,oratoria privata sive scholas”. ADWł, AV43, k. 29), par. Drzycim (,oratoria privata seu scholas”. ADWł, AV43, k. 315). informacja o zdewastowanej świątyni i o nabożeństwach, które odbywają się cztery razy do roku w szkole ${ }^{31}$.

Poprawna interpretacja kryterium formalnego zmusza często do odwoływania się do drugiego - funkcjonalno-architektonicznego. Oznacza ono, że pod uwagę brane są funkcjonujące ok. 1772 r. budynki sakralne, których głównym przeznaczeniem było sprawowanie kultu oraz posług duszpasterskich. Nie znajdzie więc swojego miejsca na mapie izba w jednym z żydowskich domów miasteczka Nowe w województwie pomorskim, o której wizytator napisał w 1780 r.: „Dantur etiam Iudaei intra oppidum estque illis in certa domo hypocaustum unum pro synagoga" ${ }^{32}$. Zgodnie z kryterium funkcjonalno-architektonicznym mapa pomija obiekty zrujnowane, istniejące $\mathrm{w}$ poprzednich stuleciach lub przeznaczone do innych celów. Niemal zawsze są to odrębne budowle, aczkolwiek zdarzały się wyjątki. Należą do nich różnego typu kaplice zamkowe czy kościoły łączone z innymi budynkami, np. ratuszem, jak w przypadku Debrzna (Frydląd Pruski): „Pr. Friedland, im Jahre 1703 erbaut als evangelisches Bethaus, aber weil in Verbindung mit einem kleinen Rathhause, so durfte sie einen Thurm erhalten und war faktisch eine Kirche. Vor dieser Kirche wurde traditionell von einem Bethause berichtet" ${ }^{\prime 3}$.

Prezentacja kartograficzna jest dość jednoznaczna i wymaga przejrzystej kategoryzacji ujmowanych zjawisk, zwłaszcza w przypadku tradycyjnej mapy drukowanej. Sytuację zmieniają interaktywne mapy internetowe oraz aplikacje GIS, co jednak stanowi odrębne zagadnienie,

29 ADWł, AV43, k. 10.

30 A. Mietz, Archidiakonat kamieński archidiecezji gnieźnieńskiej. Struktura terytorialna i stan kościotów w czasach staropolskich 1512-1772, Włocławek 2005, s. 81, 84-85, 89.

31 „Merckowitz, hat lauter Evangelisch Lutherische Inwohner, aber eigentlich keine Kirche mehr; sintemal sie verwüstet liegt. Der Gottesdienst wird in der sogenannten Schule nur vierteljährig mit Communion verrichtet. Vorhin hatten sie den Pfarrn aus Janckendorf zu ihrem Seelsorger; jetzt bedienen sie sich seit 1741. des Amts des Pastoris von Revier". Ch.S. Thomas, Altes und Neues vom Zustande der Evangelisch-Lutherischen Kirchen im Königreiche Polen, [b.m.w.] 1754, s. 113.

32 ADPel, G71, k. 252v.

33 A.G.H. Lambeck, Geschichte der Begrundung und des Wachsthums der Reformation in Westpreussen, Thorn 1850, s. 151-152. 
warte omówienia $\mathrm{z}$ punktu widzenia teorii i praktyki badawczej geografa historycznego. W przypadku map tradycyjnych możliwości percepcyjne są przyczyną ograniczenia w liczbie oraz charakterze prezentowanych elementów ${ }^{34}$. Najwyższym poziomem porządkowania materiału historycznego dotyczącego świątyń jest określenie przynależności konfesyjnej każdego z obiektów. Dwie sytuacje powodują rozliczne trudności: zmiana przynależności konfesyjnej w czasie oraz współdzielenie świątyń przez dwie różne grupy religijne, niekiedy związane z konfliktami lub rywalizacją między nimi. Dotyczy to w szczególności relacji prawosławno-unickich i katolicko-protestanckich. Na marginesie warto zauważyć, że już sama hierarchiczna struktura konfesji w Rzeczypospolitej - religia, wyznanie, obrządek - nie oddaje właściwie obowiązujących relacji społecznych i kulturowych. Podział na dwa obrządki w ramach wyznania katolickiego (grecki i łaciński) jest co najmniej tak samo istotny jak różnica między pozostałymi wyznaniami: katolicyzmem, prawosławiem, luteranizmem, kalwinizmem etc. Nakłada się na to dodatkowo przynależność terytorialna, prowincjonalna, która w przypadku protestantyzmu mogła odgrywać tak samo istotną albo nawet istotniejszą rolę jak przynależność konfesyjna ${ }^{35}$. Biorąc pod uwagę konieczność ujęcia aż 11 konfesji, za niewskazane należy uznać wprowadzanie na mapę sygnatur dla obiektów współdzielonych wyznaniowo. $Z$ tego powodu oznaczona zostanie przynależność podstawowa opisana w podstawie źródłowej, zaś informacja o drugiej konfesji znajdzie się w indeksie, ewentualnie w komentarzu do opracowania ${ }^{36}$. Należy nadmienić, że sytuacje współdzielenia świątyń przez dwie wspólnoty religijne należą do rzadkości. Częściej występują na Śląsku (np.

34 W. Ostrowski, P. Kowalski, Redakcja i reprodukcja map, w: Wprowadzenie do kartografii i topografii, s. 337.

35 W. Kriegseisen, Ewangelicy polscy i litewscy w epoce saskiej (16961763), Warszawa 1996, s. 50.

36 Odrębne sygnatury, wyróżnione kolorystycznie dla kościotów współdzielonych, luterańsko-reformowanych, wprowadzone zostały na mapie organizacji kościelnej w Prusach ok. 1785 r. Die kirchliche Organisation um 1785, Bearb. R. Ruprecht, B. Jähnig, w: Historisch-Geographischer Atlas des Preußenlandes, Hrsg. H. Mortensen, G. Mortensen, R. Wenskus, Lieferung 2, Wiesbaden 1969.
Ziębice ${ }^{37}$ ) oraz w Prusach Książęcych (np. Piława, Klikucie ${ }^{38}$ ) niż w Rzeczypospolitej. O wiele częściej można obserwować zjawisko zmiany przynależności konfesyjnej cerkwi, szczególnie w wyniku konfliktu prawosławno-unickiego w województwach bracławskim i kijowskim. Przynależność konfesyjna jest określana na podstawie masowych i przekrojowych źródeł, głównie pochodzących $\mathrm{z}$ różnych lat spisów wizytacyjnych. W rzeczywistości należałoby jednak przeprowadzić indywidualne studia dla losów kilku tysięcy cerkwi w latach 1768-1795, aby ustalić ich faktyczną przynależność wyznaniową w czasie najbardziej zbliżonym do $1772 \mathrm{r}$. Musi być tutaj przeprowadzona pełna krytyka, gdyż ten sam obiekt sakralny mógł zostać ujęty przez spisy czy wizytacje dwóch rywalizujących ze sobą na określonym terytorium konfesji. Jak złożone były to sytuacje, pokazuje np. opis cerkwi w Łukianówce, podany przez Ławrientija Pochilewicza w 1864 r. Cerkiew wybudowana w 1760 r. jako unicka, w 1768 r. przeszła w ręce prawosławne, aby powrócić do grekokatolików po upadku powstania w 1775 r. ${ }^{39}$

Drugi ważny podział świątyń, który znajduje odzwierciedlenie w symbolizacji kartograficznej, dotyczy ich hierarchii. Jest ona warunkowana funkcjami i w każdym z wyznań kształtuje się nieco odmiennie. W religii chrześcijańskiej obowiązywał w okresie nowożytnym podział na kościoły parafialne i filialne. Kategorie te znajdują pewne analogie w religii żydowskiej: synagogi kahalne i pomocnicze. Zasadniczo na mapie będzie obowiązywał podział dwustopniowy: świątynie główne i pomocnicze. W przypadku Kościoła katolickiego dodatkowe sygnatury zaplanowano dla kościołów katedralnych i kolegiackich, zarówno parafialnych (głównych), jak i filialnych (pomocniczych). Jedną z najważniejszych zmian w stosunku do poprzednich opracowań jest uporządkowanie sytuacji klasztorów i świątyń klasztornych.

\footnotetext{
37 F.A. Zimmermann, Beyträge zur Beschreibung von Schlesien, Bd. 4, Brieg 1785, s. 42

38 A. Harnoch, Chronik und Statistik der evangelischen Kirche, Neidenburg 1890 , s. $273,566$.

39 Л. Похилевич, Сказания о населённых местностях Киевской губернии, Киев 1864, s. 422.
} 
Za swego rodzaju niekonsekwencję można uznać uwzględnienie na mapie domów zakonnych i klasztorów (męskich i żeńskich), gdyż nie są to świątynie ani obiekty sakralne, których głównym przeznaczeniem było sprawowanie kultu oraz posług duszpasterskich. Wpływa na to wspomniana wyżej geneza Atlasu wyznań, który zasadniczo utrzymuje elementy ujęte w opracowaniach materiałowych poświęconych Kościołowi łacińskiemu oraz Kościołom wschodnim.

Sposób prezentacji świątyń na mapach, utrwalony już w kartografii XVIII i XIX w., związany był zazwyczaj z wprowadzeniem odrębnych sygnatur jako dodatku do symbolu miejscowości, w których takie obiekty się znajdowały. Oczywiście jest tutaj mowa o mapach małoi średnioskalowych, które najczęściej stosowane są w kartografii historycznej, gdzie miejscowości oznacza się symbolami punktowymi. W przypadku map topograficznych i wielkoskalowych, na których osady prezentowane są powierzchniowo, obiekty sakralne mają odrębne sygnatury, najczęściej jednak bez określenia ich przynależności konfesyjnej (mapy WIG) ${ }^{40}$. $\mathrm{O}$ niewielkim postępie w metodach prezentacji kartograficznej w tym zakresie świadczy sposób symbolizacji wielu obiektów sakralnych w jednej miejscowości na kościelnej mapie Węgier, Chorwacji, Słowenii i krajów sąsiednich Josepha Aszalaya de Szendrő z lat 1830-1840 ${ }^{41}$ oraz w atlasie historycznym Śląka wydanym w latach 1976-1984 ${ }^{42}$. W tym ostatnim pewnym postępem było oznaczanie cyfrą liczby obiektów sakralnych - na załączonym przykładzie (ryc. 2) widać, że w Strzegomiu znajdowały sie dwa klasztory ${ }^{43}$. Niezbyt szczęśliwie została natomiast

\footnotetext{
40 We współczesnej bazie obiektów topograficznych, w klasie określającej funkcje ogólne (OT_FunOgolnaBudynku) przewidziane zostały budynki kultu religijnego (budynkiKultuReligijnego - 1272), zaś w funkcjach szczegótowych budynków (0T_FunSzczegolowa-Budynku) wyodrębniono takie kategorie, jak: cerkiew (1272.Ck), kaplica (1272.Kp), kościół (1272.Ks), meczet (1272.Mc), synagoga (1272.Sn). Wyznanie (OT_Wyznanie), podzielone tylko na chrześcijańskie i inne, jest jednak określane tylko przy budowlach cmentarnych. Klasztor, dom zakonny czy dom parafialny zostały określone jako budynki zbiorowego zamieszkania (1130), podobnie jak np. bursy szkolne, zakłady karne czy koszary. Opis baz danych obiektów topograficznych i ogólnogeograficznych oraz standardy techniczne tworzenia map zob. Dz.U. Załącznik do nr. 279, poz. 1642 z dnia 27 grudnia 2011 r., s. 17, 121-123, 132-133, 137, 181.
}

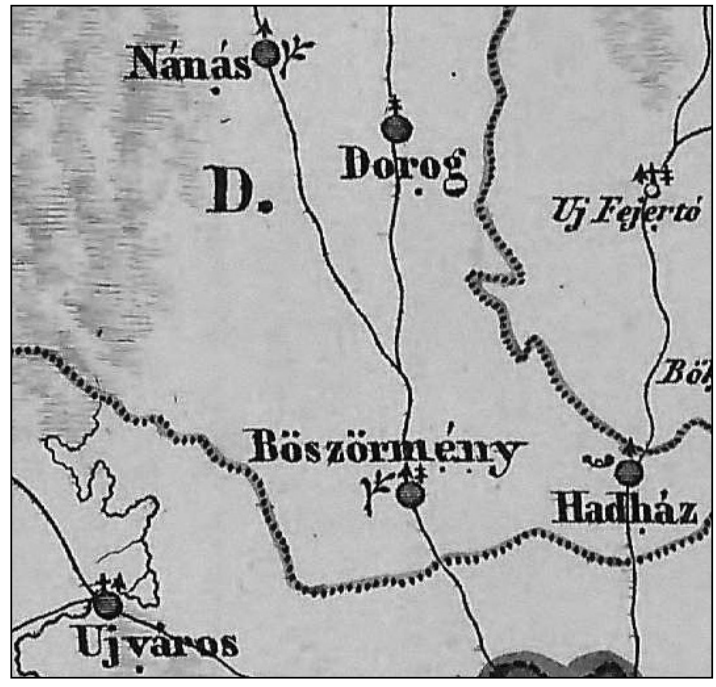

Ryc 1. J. Aszalay de Szendro”, „Mappa Generalis Topographico-Ecclesiastico-Ethnographico-Statistica Regni Hungariae partiumque adnexarum Croatiae Slavoniae et Confiniarum Militarium Magni item Principatus Transylvaniae", skala 1:700 000, Vindobonae 1830-1840.

strzatka - kościót ewangelicko-reformowany; krzyż taciński - kościót rzymskokatolicki; krzyż prawosławny - kościót greckokatolicki

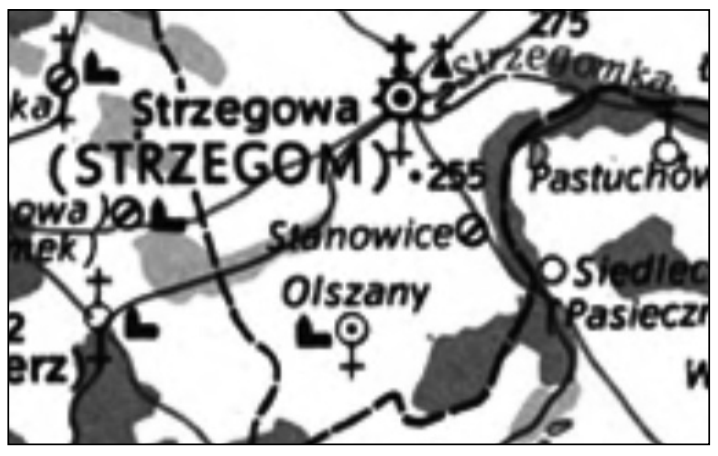

Ryc. 2. B. Kaczmarski i in., „Śląsk w końcu XVIII wieku”, skala 1:500 000, W: „Śląsk w końcu XVIII wieku”, t. 2, red. J. Janczak, cz. 1: „Mapy”, Wroctaw 1983 (Atlas historyczny Polski. Mapy XVIII wieku), tabl. 5. krzyż taciński - kościót rzymskokatolicki; odwrócony krzyż taciński - kościoty ewangelickie; krzyż taciński na trójkątnej podstawie - klasztory

41 J. Aszalay de Szendrő, Mappa Generalis Topographico-Ecclesiastico-Ethnographico-Statistica Regni Hungariae partiumque adnexarum Croatiae Slavoniae et Confiniarum Militarium Magni item Principatus Transylvaniae, skala 1:700 000, Vindobonae 1830-1840.

42 B. Kaczmarski i in., Śląsk w końcu XVIII wieku, skala 1:500 000, w: Śląsk w końcu XVIII wieku, t. 2, red. J. Janczak, cz. 1: Mapy, Wrocław 1983 (Atlas historyczny Polski. Mapy XVIII wieku), tabl. 5.

43 Podobna metoda oznaczania liczby kościołów w miejscowości cyframi została zastosowana w atlasie historycznym Kościoła ewangelickiego na Śląsku. 
dobrana sygnatura dla kościołów ewangelickich (odwrócony krzyż).

Istotny postęp w prezentacji kartograficznej obiektów sakralnych przyniosły prace Stanisława Litaka dotyczące Kościoła łacińskiego. Najtrudniejszym problemem pozostała jednak metoda właściwego przedstawienia kościołów klasztornych i samych klasztorów ${ }^{44}$. Wynika to z wieloznaczności funkcji, jakie mogły pełnić świątynie zakonne. Nie bez znaczenia jest fakt, że występowały klasztory, szczególnie żeńskie, które nie miały własnych świątyń, lecz korzystały z obiektów należących do innych zgromadzeń lub z kościołów parafialnych ${ }^{45}$. W ostatnim dużym opracowaniu poświęconym strukturom Kościoła łacińskiego w Rzeczypospolitej (wyd. 2006), które zawiera część kartograficznąa ${ }^{46}$, nastąpiły istotne uzupełnienia w porównaniu z wydaniem z 1996 r. ${ }^{47}$ Chodzi przede wszystkim o powiększenie liczby kościołów klasztornych, które pełniły rolę świątyń parafialnych i filialnych. Ze względu na małą skalę mapy głównej $(1: 800$ 000) nie można było oddać każdego z nich odrębną sygnaturą. $\mathrm{Z}$ tego powodu, tak jak $\mathrm{w}$ atlasie historycznym Śląska, w przypadku kilku zgromadzeń należących do tej samej grupy (mnisi, kanonicy regularni, klerycy regularni, zakony żebracze) zastosowano cyfry, aby oddać liczbę klasztorów większą niż jeden. $\mathrm{Z}$ powodu zastosowanej metody ich oznaczania liczba sygnatur nie zawsze odpowiada liczbie świątyń w określonej miejscowości - zostały bowiem pominięte te obiekty, które nie pełniły funkcji kościoła parafialnego lub filialnego. Niezrozumiałe jest wprowadzenie znaków dla ,innej miejscowości" (odrębnych dla miasta i wsi) w kategorii oznaczeń związanych z kościołami.

F.G.E. Anders, Historischer Atlas der Evangelischen Kirchen in Schlesien, Glogau 1856 (np. tabl. 4).

44 Klasztory zostały pominięte na mapie gtównej w pracach: S. Litak, Struktura tentorialna Kościoła łacińskiego w Polsce w 1772 roku. Mapy, Lublin 1979; tenże, Kościót taciński w Polsce około 1772 roku. Mapa - Komentarz Indeks, Rzym-Lublin 1991 (zakony męskie zostały ujęte tylko na mapie uzupełniającej: Klasztory tacińskich zakonów męskich około 1772 r.).

45 M. Borkowska, Zakony żenskie w Polsce w okresie potrydenckim, w: Zakony i klasztory w Europie Środkowo-Wschodniej. X-XX wiek, red.

H. Gapski, J. Kłoczowski, Lublin 1999, s. 232.

46 S. Litak, Atlas Kościoła tacińskiego.

47 Tenże, Kościót taciński w Rzeczypospolitej.
Sposób prezentacji tematycznej treści mapy głównej w planowanym wydawnictwie warunkowany jest zakresem terytorialnym oraz przyjętą skalą (1:300 000). Położenie sygnatury każdego obiektu nie oddaje dokładnej lokalizacji geograficznej i ma znaczenie informacyjne dotyczące przynależności świątyni lub świątyń do określonej miejscowości. Jeżeli stan wiedzy pozwala, to w przypadku miejscowości leżących nad rzekami znak obiektu sakralnego jest umieszczany po właściwej ich stronie. O nadaniu w Atlasie wyznań każdej świątyni oraz każdemu klasztorowi odrębnego symbolu na mapie głównej zdecydowały trzy powody. Po pierwsze, aby umożliwić ukazanie klasztorów, które nie miały swoich świątyń i odróżnić je od tych, które je mają. Po drugie, aby zaprezentować świątynie obsługiwane przez zakony, często z powodu stosunków własnościowych lub prawa patronatu. Kategoria taka nie była prezentowana $\mathrm{w}$ dotychczasowych ujęciach kartograficznych ${ }^{48}$. Będzie ona oddana przez literę - skrót nazwy zgromadzenia, które sprawowało opiekę nad świątynią, nawet w sytuacji gdy nie było przy niej klasztoru. Po trzecie wreszcie, ze względu na dość trudne oddzielenie świątyń klasztornych, które miały dodatkowe funkcje parafialne lub filialne, od tych, które takich zadań nie pełniły. W stosunku do istniejących wcześniej opracowań bardziej rygorystycznie zostaną też potraktowane same klasztory. Stanisław Litak, idąc przeważnie za wykazami publikowanymi w opracowaniu Zakony męskie w Polsce w 1772 roku. ${ }^{4}$, traktował je w swoich zestawieniach oraz mapach jednakowo i umieszczał na mapie zarówno duże konwenty czy opactwa, jak i misje szkolne (jezuici), rezydencje czy prepozytury (benedyktyni, kanonicy regularni laterańscy). Te ostatnie nie mogą być jednak traktowane w kategorii klasztoru, a oznaczają jedynie zamieszkiwanie 1, 2, a niekiedy 3 zakonników przy kościele,

\footnotetext{
48 Kategorie parafii przyklasztornych oraz administrowanych występują w cytowanych wyżej wykazach Stanisława Litaka oraz w opracowaniu Jerzego Flagi Zakony męskie w Polsce w 1772 roku. Duszpasterstwo, Lublin 1991 (Materiały do Atlasu Historycznego Chrześcijaństwa w Polsce, 8), s. 11.

49 Zakony męskie w Polsce w 1772 roku, red. L. Bieńkowski, J. Kłoczowski, Z. Sułowski, Lublin 1972
} 
który znajdował się pod ich opieką lub przy którym sprawowali posługę, wspierając duchowieństwo świeckie.

$\mathrm{Z}$ wyżej wymienionych przyczyn Atlas wyznań pomija np. „klasztor” benedyktynów w Siemowie, gdzie znajdował się kościół filialny jedynie obsługiwany przez benedyktynów z Lubina (Siemowo było własnością benedyktynów lubińskich, którzy sprawowali patronat nad tamtejszą parafią) $)^{50}$. Analogiczna sytuacja występuje w parafii w Koniemłotach w diecezji krakowskiej, która była obsługiwana przez benedyktynów ze Świętego Krzyża. Posiadali oni co prawda prawo patronatu do tej parafii i wyznaczali zakonników ze swojego zgromadzenia do posługi duszpasterskiej, ale związki własnościowe zostały zerwane już w XVI w. (zamiana dóbr) i nie było tam klasztoru ${ }^{51}$. Należy zresztą zaznaczyć, że obiekty te, podobnie jak wiele innych, nie były ujmowane na mapach klasztorów męskich opracowanych przez Adama Chruszczewskiego ${ }^{52}$ czy w pracy Zakony meskie w Polsce w 1772 roku $^{53}$. Podobnej weryfikacji w stosunku do poprzednich opracowań ulegnie status wielu ośrodków związanych z bożogrobcami, cystersami, jezuitami czy kanonikami regularnymi laterańskimi.

\section{Granice}

Harmonizacja oraz generalizacja dla potrzeb prezentacji kartograficznej musiała objąć także granice jednostek administracji wyznaniowej. Kształtowanie ładu przestrzennego poszczególnych wyznań jest procesem o różnej dynamice, warunkowanym bardzo wieloma czynnikami: politycznymi, religijnymi, społecznymi i majątkowymi. Elementy te mogą wpłynąć na ukształtowanie bardzo rozbudowanych i dobrze zorganizowanych struktur;

\footnotetext{
50 „Regestr diecezjów” Franciszka Czaykowskiego czyli właściciele ziemscy w Koronie 1783-1784, oprac. K. Chłapowski, S. Górzyński, Warszawa 2006, s. 821; J. Nowacki, Dzieje archidiecezji poznańskiej, t. 2, Poznań 1964 , s. 414, 756. Stanisław Litak potraktowat tę parafię jako kościót filialny. Zob.: AAP, AV24, k. 294, 1737 r.; AAP, AV32 s. 304, 1777 r. Nie można wykluczyć inkorporacji albo unii beneficjów. 51 AKMK, AV56, s. 229-230. Prawdopodobnie ze względu na fakt zamieszkania tam 3 zakonników w spisie beneficjów z 1787 r. obok Świętego Krzyża i Sieciechowa pojawia się sformułowanie: „Patres
}

z drugiej jednak strony mogą zdecydować o ich braku. Większość założeń dotyczących kartograficznej prezentacji grup wyznaniowych przyjmuje ich terytorialność, podział przestrzeni. Teza ta obowiązuje dla zwartych i hierarchicznych struktur charakterystycznych dla Kościoła katolickiego różnych obrządków. Struktura terytorialna, dotycząca hierarchicznego i uporządkowanego Kościoła łacińskiego czy unickiego bez większych trudności może być prezentowana w postaci map oraz wykazów. Podobnie będzie z Kościołem luterańskim na Śląsku, w Prusach Książęcych i Inflantach. Modelu tego nie można jednak w sposób prosty przenieść na inne konfesje. Czynnik terytorialny odgrywał w kształtowaniu zależności i hierarchii mniejszą rolę w sytuacji mniejszości religijnych, gdzie obiekty sakralne i związane z nimi wspólnoty występowały rzadko i nieregularnie.

Atlas wyznań $i$ religii będzie prezentował granice jednostek administracyjnych Kościołów łacińskiego, unickiego oraz luterańskiego (na Śląsku, w Prusach Książęcych i w Inflantach). Organizacja Kościoła prawosławnego na Rusi Koronnej i w Wielkim Księstwie Litewskim w końcu istnienia Rzeczypospolitej była skromna. Ograniczała się do diecezji mohylewskiej, której zasięg pokrywał się z unicką diecezją połocką. Zwierzchność nad pozostałymi cerkwiami sprawowali metropolita kijowski i biskup perejasławski ${ }^{54}$. Zrezygnowano także z prezentacji jednostek terytorialnych administracji żydowskiej. Zakres chronologiczny projektu wyznacza data pierwszego rozbioru Polski, zaś w 1764 r. nastąpiła likwidacja sejmów i ziemstw żydowskich, co oznaczało - choć trudno określić jak szybki - rozpad istniejących wcześniej struktur

Benedictini - In Koniomłoty residentia". Pominięte zostały natomiast inne parafie obsługiwane przez benedyktynów w diecezji krakowskiej, m.in.: Puchaczów, Wąwolnica, Brzeźnica, Radom Stary.

52 A. Chruszczewski, Zakony męskie w Polsce XVII i XVIII w., w: Kościót w Polsce, red. J. Kłoczowski, t. 2, Kraków 1969, mapa 11.

53 Benedyktyni 1772. Kongregacja polska i Śląsk, w: Zakony męskie w Polsce w 1772 roku, mapa IX.

54 L. Bieńkowski, Organizacja Kościoła wschodniego w Polsce, w: Kościót w Polsce, t. 2, Kraków 1969, s. 858; W. Kołbuk, Kościoły wschodnie, s. 67. 
terytorialnych ${ }^{55}$. Stan badań nad organizacją terytorialną Żydów w Polsce przedrozbiorowej, mimo rozwoju w ostatnich dekadach, ciągle jeszcze nie pozwala na kompletną rekonstrukcję w skali całego kraju. Istnieją daleko idące rozbieżności między specjalistami w tej dziedzinie; główne stanowiska zreferował częściowo Anatol Leszczyński ${ }^{56}$. Dużą szansę na taką rekonstrukcję dotyczącą okresu sprzed 1764 r. stwarzają ostatnie prace Judith Kalik (dla Korony) oraz Jurgity Šiaučiūnaitè-Verbickienè i Anny Michałowskiej-Mycielskiej (dla Litwy) ${ }^{57}$. W przypadku kościołów katolickich obrządku ormiańskiego, świątyń kalwińskich, mennonickich i hernhuckich, kienes oraz meczetów ze względu na ich niewielką liczbę i znaczne rozproszenie trudno mówić o innych strukturach terytorialnych niż pojedyncze wspólnoty.

Mimo pominięcia podziałów terytorialnych prawosławnych (poza diecezją mohylewska) i żydowskich harmonizacja granic trzech prezentowanych konfesji również nie należy do najłatwiejszych. Większych trudności nie sprawia przyporządkowanie łacińskich i unickich struktur organizacyjnych. Łacińskim dekanatom odpowiadają unickie protopopie (namiestnictwa), archidiakonatom - namiestnictwa generalne (kryłosy, oficjalaty), zaś diecezjom - eparchie. Na ma konieczności zaznaczania granic metropolii unickiej, gdyż cały teren Rzeczypospolitej należał do jednej - kijowskiej. O wiele bardziej złożona i wymagająca komentarza jest sytuacja Kościoła luterańskiego.

Każdy z terenów, na których występowały zwarte struktury tego wyznania, miał nieco odmienną organizację terytorialną. Jeżeli cho-

55 J. Goldberg, Żydowski Sejm Czterech Ziem w spotecznym i politycznym ustroju dawnej Rzeczypospolitej, w: Żydzi w dawnej Rzeczypospolitej, red. A. Link-Lenczowski, T. Polański, Wrocław-Warszawa-Kraków 1991, s. 57; A. Michałowska-Mycielska, Sejm Żyów litewskich (1623-1764), Warszawa 2014 [ePUB], s. 369-370.

56 A. Leszczyński, Sejm Żydów Korony 1623-1764, Warszawa 1994, S. 67-68.

${ }^{77}$ A. Michałowska-Mycielska, Sejm Żydów litewskich; J. Šiaučiūnaitè-Verbickienè, Žydai Lietuvos Didžiosios Kunigaikštystés visuomenèje: sambūvio aspektai, Vilnius 2009; J. Kalik, Scepter of Judah. The Jewish Autonomy in the Eighteenth-Century Crown Poland, Leiden 2009. dzi o Prusy Książęce, nie można zastosować wprost ustaleń poczynionych $\mathrm{w}$ atlasie historycznym Prus, gdyż zamieszczona tam mapa struktur oddaje sytuację ok. 1785 r. ${ }^{58}$ Pierwszy rozbiór Polski pociągną za sobą także znaczące zmiany w organizacji Kościoła luterańskiego, a najważniejszą było powołanie konsystorza zachodniopruskiego ${ }^{59}$.

W literaturze przedmiotu sporo zamieszania wprowadza dość nieostrożna interpretacja, a czasem zamienne traktowanie świeckich i kościelnych jednostek administracyjnych w Prusach ${ }^{60}$. Mimo daleko posuniętej zgodności podziałów kościelnych i państwowych nie była ona pełna i nie można porządkować inspekcji (jednostki kościelne) wg podziału na prowincje (jednostki państwowe) Prus (Natangia, Sambia, Prusy Górne i Królewiec) ${ }^{61}$. Jednostką nadrzędną wobec inspekcji był konsystorz. Do poł. XVIII w. istniały dwa konsystorze, które powstały w 1587 r. na bazie dwóch dawnych diecezji katolickich: sambijskiej i pomezańskiej. Siedziba konsystorza sambijskiego znajdowała sie w Królewcu, zaś pomezańskiego - w Zalewie. W 1751 r., po utworzeniu nadkonsystorza dla całej monarchii w Berlinie, został zlikwidowany konsystorz Zalewie i pozostał tylko jeden dla całej prowincji - pruski $^{62}$. Nie zawsze też granice inspekcji pokrywały się z granicami starostw $(A m t)^{63}$; za przykład takich rozbieżności

58 Die kirchliche Organisation um 1785.

59 W. Hubatsch, Geschichte der evangelischen Kirche Ostpreussens, Bd. 1, Göttingen 1968, s. 229.

60 T. Nowicki, Uwagi o organizacji Kościoła luterańskiego w Prusach Wschodnich w latach osiemdziesiątych XVIII wieku, „Roczniki Humanistyczne", 48 (2), 2000, s. 92-93.

61 Zabieg taki chyba nazbyt pochopnie znalazł się w opracowaniu Walthera Hubatscha (W. Hubatsch, Geschichte der evangelischen Kirche Ostpreussens, Bd. 3, s. 416-426), który na podstawie wykazu Ludwiga Ernsta Borowskiego podzielit inspekcje Prus Wschodnich na 4 prowincje: I. Haupstadt Königsberg, II. Kirchenprovinz Samland, III. Kirchenprovinz Natangen, IV. Kirchenprovinz Oberland. W wykazie Borowskiego nie ma jednak mowy o prowincjach kościelnych, po prostu używa on określenia „prowincja” (Provinz). L.E. Borowski, Neue Preussische Kirchenregistratur, Königsberg 1789, s. 195-210.

62 M. Töppen, Historisch-comparative Geographie von Preussen, Gotha 1858, s. 287; W. Hubatsch, Geschichte der evangelischen Kirche Ostpreussens, Bd. 1, s. 220

63 „Die Grenzen der geistlichen Sprengel fallen mit den Grenzen der Hauptämter meistenheils zusammen, wenngleich ein Amt zwei Inspektionen und eine ziemliche Anzahl der Inspektionen mehrere Aemter enthält". M. Töppen, Historisch-comparative Geographie, s. 289. 
mogą posłużyć parafie Rozogi (Friedrichsdorf, Rosoggen) oraz Jerutki (Jerutten) ${ }^{64}$.

W opinii autorów mapy struktur religijnych w Prusach Wschodnich luterańskie inspekcje można zestawiać z katolickimi dekanatami, zaś luterańskie konsystorze $-\mathrm{z}$ diecezjami ${ }^{65}$. Przyjęcie takiego założenia uniemożliwia jednak wprowadzenie na mapę główną senioratów jako najniższej jednostki administracji luterańskiej na Śląsku ${ }^{66}$. Sytuację dodatkowo komplikuje za-
Wyznaczenie przebiegu granic kościelnych odbywa się w zasadzie metodą interpolacji między punktami oznaczającymi obiekty sakralne. Sa przy tym wykorzystywane elementy fizjografii terenu - głównie rzeki. W rekonstrukcji uwzględnia się także najważniejsze prace atlasowe, takie jak poszczególne tomy „Atlasu historycznego Polski” czy atlas historyczny Prus ${ }^{69}$. Prowadzenie granic linearnych dla jednostek administracji kościelnej ma przede wszystkim

Tab. 1. Kategorie jednostek administracji terytorialnej Kościotów tacińskiego, unickiego i luterańskiego w 2. pot. XVIII w.

\begin{tabular}{|c|c|c|}
\hline Kościół laciński & Kościół unicki & Kościół luterański \\
\hline diecezja & eparchia / diecezja & konsystorz \\
\hline archidiakonat / prepozytura / dziekania & namiestnictwo generalne / kryłos / oficjalat & superintendentura / inspekcja / prepozytura \\
\hline dekanat & protopopia / namiestnictwo & seniorat (na Śląsku) \\
\hline
\end{tabular}

mienne używanie dla struktur śląskich określeń "Superintendentur", „Inspektion” i „Diöcese" 67. Z kolei w Kurlandii i ziemi piltyńskiej podstawową jednostką organizacji luterańskiej w 2. poł. XVIII w. były prepozytury (Praepositur), które wykazują analogie z inspekcjami śląskimi i pruskimi ${ }^{68}$. Biorąc pod uwagę wielkość jednostek administracyjnych oraz ich układ hierarchiczny w Kościele katolickim obrządków łacińskiego i greckiego oraz w Kościele luterańskim na Śląsku, w Prusach Książęcych i w Rzeczypospolitej (Inflanty, ziemie lęborska i bytowska), w Atlasie wyznań $i$ religii zostanie prawdopodobnie przyjęta harmonizacja granic kościelnych (przy wyłączeniu metropolii, które będą oznaczone jedynie dla Kościoła łacińskiego) określona w tabeli 1.

${ }^{64}$ „Aus dem Ortelsburgschen [Szczytno] in dem Oberlande gelegenen Amte, gehören folgende zwey Kirchen noch zur Inspection des Rastenburgischen Erzpriesters [Kętrzyn]". D.H. Arnoldt, Kurzgefaßte Nachrichten von allen seit der Reformation an den Lutherischen Kirchen in Ostpreußen gestandenen Predigern, Königsberg 1777, s. 306. W świetle powyższego starostwo (Amt) Szczytno było podzielone między dwie inspekcje: Zalewo i Kętrzyn. Tamże, s. 464-462. Por. też M. Töppen, Historisch-comparative Geographie, s. 290.

65 Die kirchliche Organisation um 1785 (wstęp do mapy).

66 Stanisław Litak nieco błędnie zakładał, że seniorat i inspekcja to jednostki administracyjne należące do tej samej kategorii. S. Litak, Mapa wyznaniowa Rzeczypospolitej, s. 351.

67 Friedrich Gottlieb Eduard Anders w spisie jednostek administracyjnych używa określenia „Diöcese”, zaś na mapie jednostkę tę nazywa „Inspektion” lub „Superintendentur”. Zob. np. F.G.E. Anders, Historischer znaczenie informacyjne i oddaje przynależność poszczególnych obiektów sakralnych do jednostek terytorialnych. Dokładność topograficzna ich przebiegu ma tu znaczenie całkowicie drugorzędne. Ze względu na duże nagromadzenie granic i podziałów administracyjnych (do granic kościelnych dochodzą też państwowe szczebla wojewódzkiego) na mapie głównej zdecydowano się uprościć ich prezentację. Granice kościelne, które na dłuższych odcinkach pokrywały się z państwowymi lub granicami Śląska, zostaną usunięte. Pozostaną jedynie „wąsy” wskazujące kierunek przebiegu granicy metropolii, diecezji, konsystorza lub inspekcji wzdłuż granic państwowych lub granicy Śląska. To samo dotyczy przebiegu granicy państwa, jeżeli na dłuższym

\footnotetext{
Atlas der Evangelischen Kirchen; tenże, Historische Statistik der Evangelischen Kirche in Schlesien nebst einer Kirchenkarte, Breslau 1867, s. 53-57. 0 zamiennym stosowaniu terminów „diecezja” i „inspekcja” świadczy też sformułowanie w pracy Sigismunda Justusa Ehrhardta z 1780 r. na temat diecezji wrocławskiej: „Die dioeces eines Breslauer Inspektors ist sehr gros". S.J. Ehrhardt, Presbyterologie des evangelischen Schlesiens, Bd. 1, Liegnitz 1780, s. 164.

68 C.L. Tetsch, Curländischer Kirchen-Geschichte, Bd. 1, Riga-Leipzig 1767, s. 271-284. Warto zauważyć, że termin „Inspektion” w Prusach Książęcych funkcjonował w XVIII w. równolegle z określeniem „Erzpriestertum”. W. Hubatsch, Geschichte der evangelischen Kirche Ostpreussens, Bd. 3, s. 406-426; M. Töppen, Historisch-comparative Geographie, s. 289.

69 S. Litak, Mapa wyznaniowa Rzeczypospolitej, s. 351-352.
} 
dystansie opierała się ona na ważnych rzekach (zasada kartograficzna przyjęta w XVIII w. na mapach szczególnych Karola Perthéesa). Pozostawiono jednocześnie pełny rysunek granic kościelnych w przypadku pokrywania się ich $\mathrm{z}$ granicami województw.

\section{Podsumowanie}

Powyższe uwagi wskazują, że ujęcie na jednej mapie wielu grup religijnych i wyznaniowych musi być poprzedzone pogłębioną refleksją nad strukturą organizacyjną oraz terytorialną każdej $\mathrm{z}$ nich. Przedstawione wyżej wnioski nie mają charakteru ostatecznego i wynikają z aktualnego stanu wiedzy i materiału zgromadzonego dla poszczególnych świątyń oraz jednostek administracyjnych; warto dodać - materiału zróżnicowanego w zawartości treściowej i formie (źródła pisane i kartograficzne). Dwie konkluzje nasuwają się w sposób dość oczywisty. Po pierwsze, prezentacja obiektów sakralnych i struktury terytorialnej wielu wyznań zmusza do daleko idących generalizacji i uproszczeń, których świadom powinien być także odbiorca takich opracowań. Uproszczenia te dotyczą nie tylko sposobu prezentacji kartograficznej (dokładność położenia świątyń, schematyczny i informacyjny przebieg granic), ale także kategoryzacji prezentowanych zjawisk (typy świątyń, przynależność konfesyjna, poziomy podziałów terytorialnych). W związku z tym - i jest to druga konkluzja - niezbędnymi elementami opracowań o takim charakterze muszą być komentarz merytoryczny oraz indeks zawierający podstawę źródłową i uwagi. Umożliwiają one wyjaśnienie zasad oraz wątpliwości, które stanowi uzupełnienie prezentacji kartograficznej.

Zadaniem Atlasu wyznań $i$ religii jest rekonstrukcja podziałów terytorialnych, religii i wyznań obecnych na terenie Rzeczypospolitej, Śląska i Prus Książęcych w momencie dokonywania pierwszego rozbioru (ok. 1772). Zarówno zakres rzeczowy, terytorialny, jak i chronologiczny mogą być dyskusyjne. Rzeczowy - poprzez uwzględnienie na mapie i w zestawieniu klasztorów, terytorialny - poprzez włączenie Śląska i Prus Książęcych jako terytoriów nieleżących w granicach Rzeczypospolitej, zaś chronologiczny - poprzez ważne wydarzenia w życiu kraju, które poprzedzały pierwszy rozbiór i wpłynęty na kształt administracyjny i organizacyjny poszczególnych konfesji: zmiana sytuacji prawnej innowierców, koliwszczyzna, likwidacja samorządu żydowskiego. Okoliczności te wskazują, że geografia wyznań i religii powinna być w przyszłości prezentowana także w ujęciu diachronicznym, które umożliwi pełną obserwację i analizę czynników wpływających na obraz konfesyjny $\mathrm{kraju}^{70}$. Dziś pozwala na to już nie tylko tradycyjna kartografia (mapy rozwojowe), ale także czasowo-przestrzenne bazy danych i mapy interaktywne, które ułatwiają prezentację zjawisk w czasie i pomagają rozwiązywać skomplikowane sytuacje charakterystyczne dla rozważań historycznych.

\section{Bibliografia}

\section{Źródła rękopiśmienne}

Archiwum Archidiecezjalne w Poznaniu (AAP)

AV24, Wizytacja archidiakonatu Śrem, 17371738.

AV31, Wizytacja archidiakonatu Poznań, 1777-1784.

AV32, Wizytacja archidiakonatu Śrem, 17771778.

AV33, Wizytacja archidiakonatu Śrem, 1777 1783.

Archiwum Diecezjalne w Pelplinie (ADPel)

G71, Wizytacja dekanatów Nowe Miasto i Gniew, 1780-1781.

Archiwum Diecezjalne we Włocławku (ADWt) AV43, Wizytacja dekanatów Świecie i Fordon, 1780.

\footnotetext{
70 J. Gaudemet, Géographie ecclésiastique, s. 259.
} 
GAV86, Wizytacja dekanatu Krotoszyn, 1790.

Archiwum Kurii Metropolitalnej w Krakowie (AKMK)

Źródła drukowane

Arnoldt D.H., Kurzgefaßte Nachrichten von allen seit der Reformation an den Lutherischen Kirchen in Ostpreußen gestandenen Predigern, Königsberg 1777.

Borowski L.E., Neue Preussische Kirchenregistratur, Königsberg 1789.

Ehrhardt S.J., Presbyterologie des evangelischen Schlesiens, Bd. 1, Liegnitz 1780.

"Regestr diecezjów” Franciszka Czaykowskiego czyli wtaściciele ziemscy w Koronie 1783-1784,

Mapy i atlasy

Anders F.G.E., Historischer Atlas der Evangelischen Kirchen in Schlesien, Glogau 1856.

Aszalay de Szendrö J., Mappa Generalis Topographico-Ecclesiastico-Ethnographico-Statistica Regni Hungariae partiumque adnexarum Croatiae Slavoniae et Confiniarum Militarium Magni item Principatus Transylvaniae, skala 1:700 000, Vindobonae 1830-1840.

Kaczmarski B. i in., Ślask w końcu XVIII wieku, skala 1:500 000, w: Sląsk w końcu XVIII

Literatura

Anders F.G.E., Historische Statistik der Evangelischen Kirche in Schlesien nebst einer Kirchenkarte, Breslau 1867.

Bieńkowski L., Organizacja Kościota wschodniego $w$ Polsce, w: Kościót w Polsce, red. J. Kłoczowski, t. 2, Kraków 1969, s. 779-1049.

Borkowska M., Zakony żeńskie $w$ Polsce $w$ okresie potrydenckim, w: Zakony i klasztory $w$ Europie Środkowo-Wschodniej. X-XX wiek, red. H. Gapski, J. Kłoczowski, Lublin 1999, s. $197-$ 243.

Cartographic Activities in Poland 2011-2014. National Report, ed. B. Konopska, J. Ostrowski, Warszawa 2015 (http://icaci.org/files/ documents/national_reports/2011-2015/ poland.pdf, dostęp: 5 września 2015).

Flaga J., Zakony męskie w Polsce w 1772 roku. Duszpasterstwo, Lublin 1991 (Materiały do
AV56, Wizytacja dekanatów Pacanów, Opatowiec, Witów, Sokolina, 1783.

oprac. K. Chłapowski, S. Górzyński, Warszawa 2006.

Tetsch C.L., Curländischer Kirchen-Geschichte, Bd. 1, Riga-Leipzig 1767.

Thomas Ch.S., Altes und Neues vom Zustande der Evangelisch-Lutherischen Kirchen im Königreiche Polen, [b.m.w.] 1754.

Zimmermann F.A., Beyträge zur Beschreibung von Schlesien, Bd. 4, Brieg 1785.

wieku, t. 2, red. J. Janczak, cz. 1: Mapy, Wroclaw 1983 (Atlas historyczny Polski. Mapy XVIII wieku), tabl. 5.

Die kirchliche Organisation um 1785, Bearb. R. Ruprecht, B. Jähnig, w: Historisch-Geographischer Atlas des Preußenlandes, Hrsg. H. Mortensen, G. Mortensen, R. Wenskus, Lieferung 2, Wiesbaden 1969.

Atlasu Historycznego Chrześcijaństwa w Polsce, 8).

Gaudemet J., Géographie ecclésiastique et histoire des institutions, w: Miscellanea historiae ecclesiasticae V. Colloque de Varsovie, 27-29 octobre 1971 sur la cartographie et l'histoire socio-religieuse de l'Europe jusqu'à la fin du XVIIe siècle, s. 260-274.

Goldberg J., Żydowski Sejm Czterech Ziem $w$ spotecznym $i$ politycznym ustroju dawnej Rzeczypospolitej, w: Żydzi w dawnej Rzeczypospolitej, red. A. Link-Lenczowski, T. Polański, Wrocław-Warszawa-Kraków 1991, s. 44-58.

Harnoch A., Chronik und Statistik der evanglischen Kirche, Neidenburg 1890.

Hubatsch W., Geschichte der evangelischen Kirche Ostpreussens, Bd. 1-3, Göttingen 1968. 
Kalik J., Scepter of Judah. The Jewish Autonomy in the Eighteenth-Century Crown Poland, Leiden 2009.

Klemp A., Protestanci $w$ dobrach prywatnych $w$ Prusach Królewskich od drugiej potowy XVII do drugiej potowy XVIII wieku, Gdańsk -Wrocław 1994.

Kłoczowski J., Rozwój i problematyka badań nad geografia historyczna Kościota Katolickiego, „Roczniki Humanistyczne”, 11 (2), 1962, s. 5-93.

Kołbuk W., Kościoty wschodnie w Rzeczypospolitej okoto 1772 r., Lublin 1998.

Kościót w Polsce, red. J. Kłoczowski, t. 2, Kraków 1969.

Kriegseisen W., Ewangelicy polscy i litewscy w epoce saskiej (1696-1763), Warszawa 1996.

Kriegseisen W., Stosunki wyznaniowe w relacjach pañstwo-kościót między reformacją $i$ oświeceniem, Warszawa 2010.

Lambeck A.G.H., Geschichte der Begrundung und des Wachsthums der Reformation in Westpreussen, Thorn 1850.

Le Bras G., Un programme: la géographie religieuse, „Annales d'histoire sociale”, 8 (1), 1945, s. $87-112$.

Leszczyński A., Sejm Żydów Korony 1623-1764, Warszawa 1994, s. 67-68.

Litak S., Atlas Kościota tacińskiego w Rzeczypospolitej Obojga Narodów w XVIII wieku, Lublin 2006.

Litak S., The Atlas of Religious and Ethnic Relations in the Polish-Lithuanian Commonwealth in the Second Half of the $18^{\text {th }}$ Century, w: Churches, States, Nations in the Enlightenment and in Nineteenth Century. Eglises, états, nations a l'epoque des Lumières et au XIXe siècle, ed. M. Filipowicz, Lublin 2000, s. 54-59.

Litak S., Kościót tacinsski w Polsce okoto 1772 roku. Mapa - Komentarz - Indeks, RzymLublin 1991.

Litak S., Kościót taciński w Rzeczypospolitej okoto $1772 r$. Struktury administracyjne, Lublin 1996.

Litak S., Mapa wyznaniowa Rzeczypospolitej okoto 1772 roku (Religie - Wyznania - Kościoty-Metoda opracowania), w: Jezuicka ars historica. Prace ofiarowane Księdzu Profesorowi
Ludwikowi Grzebieniowi SJ, red. M. Inglot, S. Obirek, Kraków 2001, s. 345-354.

Litak S., Projekt wyznaniowej mapy Rzeczypospolitej $w$ drugiej potowie XVIII w., w: Mapa w pracy historyka, red. T. Bogacz, B. Konopska, Wrocław-Warszawa 1999, s. 175-184 (Z Dziejów Kartografii, 11).

Litak S., Struktura terytorialna Kościota tacinskiego $w$ Polsce $w 1772$ roku. Mapy, Lublin 1979.

Mazurkiewicz S., Nekla. Historia miasta. Monografia na jubileusz 600-lecia, Września-Nekla 2007.

Merczyng H., Zbory i senatorowie protestanccy $w$ dawnej Polsce, w: W. Krasiński, Zarys dziejów powstania $i$ upadku reformacji $w$ Polsce, Warszawa 1905, s. 125-263.

Michałowska-Mycielska A., Sejm Żydów litewskich (1623-1764), Warszawa 2014 [ePUB].

Mietz A., Archidiakonat kamieński archidiecezji gnieźnieńskiej. Struktura terytorialna i stan kościołów w czasach staropolskich 1512-1772, Włocławek 2005.

Miscellanea historiae ecclesiasticae V. Colloque de Varsovie, 27-29 octobre 1971 sur la cartographie et l'histoire socio-religieuse de l'Europe jusqu'à la fin du XVIIe siècle, Louvain 1974 (Bibliothèque de la Revue d'histoire ecclésiastique, 61).

Nowacki J., Dzieje archidiecezji poznañskiej, t. 2, Poznań 1964, s. 414, 756.

Nowicki T., Uwagi o organizacji Kościota luterańskiego $w$ Prusach Wschodnich $w$ latach osiemdziesiatych XVIII wieku, „Roczniki Humanistyczne”, 48 (2), 2000, s. 91-111.

Ogólnopolska sesja naukowa $z$ dnia 25 listopada 1966 r. poświęcona dziatalności naukowej Instytutu Geografii Historycznej Kościoła w Polsce, „Roczniki Humanistyczne”, 16 (2), 1968, s. $123-174$.

Ostrowski W., Kowalski P., Redakcja i reprodukcja map, w: Wprowadzenie do kartografii i topografii, red. J. Pasławski, Wrocław 2006, s. 330-356.

Pasławski J., Siwek J., Mapy tematyczne, w: Wprowadzenie do kartografii i topografii, red. J. Pasławski, Wrocław 2006, s. 307-329. 
Šiaučiūnaitè-Verbickienè J., Žydai Lietuvos Didžiosios Kunigaikstystés visuomeneje: sambüvio zaspektai, Vilnius 2009.

Szady B., Geografia struktur religijnych $i$ wyznaniowych $w$ Koronie $w$ II potowie XVIII wieku, Lublin 2010.

Szady B., $Z$ badań nad mapa wyznań i religii Rzeczypospolitej przed pierwszym rozbiorem Polski, w: Rzeczpospolita wielokulturowa - dobrodziejstwo czy obciażenie, red. J. Kłoczowski, Warszawa 2009, s. 21-27.
Töppen M., Historisch-comparative Geographie von Preussen, Gotha 1858.

Werner A., Geschichte der evangelischen Parochien in der Provinz Posen, Lissa 1904.

Zakony meskie w Polsce w 1772 roku, red. L. Bieńkowski, J. Kłoczowski, Z. Sułowski, Lublin 1972.

Żyszkowska W., Spallek W.A., Borowicz D., Kartografia tematyczna, Warszawa 2012.

Похилевич $\Lambda$., Сказания о населённых местностях Киевской губернии, Киев 1864.

\section{Religious Structures on the Example of "Atlas of Religions and Confessions in the Polish-Lithuanian Commonwealth in the $2^{\text {nd }}$ Half of the $18^{\text {th }}$ Century"}

\section{Summary}

The present article deals with harmonization of selected geographical and historical information on territorial structures of religions and denominations in the $18^{\text {th }}$ century Polish-Lithuanian Commonwealth and their cartographical presentation. It refers to two categories constituting the content of the map, namely churches and units of territorial administration of particular religions. The Author focuses on problems concerning interpretation of written and cartographic sources as well as the methods of transferring those interpretations onto the cartographic form, which requires precision and accuracy. He indicates the criteria for the qualification of sacral places (in the formal and functional-architectural aspects) which detertheir inclusion in "Atlas of Religions and Confessions in the Polish-Lithuanian Com- monwealth in the $2^{\text {nd }}$ Half of the $18^{\text {th }}$ Century" Referring to the tradition of the existing cartographic forms, the Author discusses the categories of sacral places and the methods of presenting them in the main map in the scale 1:300 000 . In the case of borders, the Author focused attention on the problem of harmonization of territorial structures of the Latin, Lutheran and Jewish denominations. The conclusion emphasizes the necessity for generalization and simplification of the presented phenomena which the recipient of cartographic presentations should be aware of. At the same time, the Author indicated a need for reliable information to be reflected in a content-related commentary and an index including the source basis and all kinds of remarks concerning the map.

Słowa kluczowe: Rzeczpospolita Obojga Narodów, administracja terytorialna, religie i wyznania, świątynie i kościoły, kartografia historyczna

Keyw ords: Polish-Lithuanian Commonwealth, territorial administration, religions and denominations, churches, historical cartography

dr hab. Bogumił Szady - profesor nadzwyczajny w Instytucie Historii KUL, pracownik w Zakładzie Atlasu Historycznego Instytutu Historii PAN im. Tadeusza Manteuffla (e-mail: szady@kul.pl) 